\title{
Life After Defined Benefit Plans
}

\author{
Martin A. Goldberg, (Email: mgoldberg@newhaven.edu), University of New Haven
}

Robert E. Wnek, (Email: rwnek@newhaven.edu), University of New Haven

Michael J. Rolleri, (Email: mrolleri@newhaven.edu), University of New Haven

\begin{abstract}
Employers have moved from traditional pension plans to cash balance and other alternative defined benefit plans. However, it may be that the best approach lies beyond defined benefit plans completely. The Employee Retirement Income Security Act of 1974 (ERISA) was enacted to protect workers. Its focus was on the defined benefit plan, which at that time meant a traditional pension plan that provided lifetime income to retired workers. Over the years traditional pension plans have declined in number, often due to their increasing costs. Many of these plans have been replaced by the $401(k)$ plan, a profit-sharing plan partly or wholly funded by employee contributions. There has also been a rise in hybrid plans, plans that have features of both defined benefit and defined contribution plans. Recent developments highlight the weaknesses in traditional pension plans. Replacing a traditional pension plan with a cash balance plan, a hybrid plan that qualifies as a defined benefit plan, does not fully address all the problems. It may be that there is limited advantage to the continued emphasis on defined benefit plans. Instead, defined contribution plans that contain some features of defined benefit plans may better address the current retirement-plan issues.
\end{abstract}

\section{INTRODUCTION}

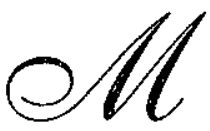

any workers have ultimately lost their benefits - even after relatively long service - because when they left jobs, they thereby gave up rights to hard-earned pension benefits. Others have sustained hardships because their companies folded with insufficient funds in the pension plan to pay promised pensions.'

The fragile state of our nation's pension plans has caught the attention of Americans everywhere. ${ }^{2}$

These two quotes appear to be in agreement, almost as though a dialogue between two individuals speaking together. However, the two statements were made more than 30 years apart. The first was by President Gerald $R$. Ford, when he signed law the Employee Retirement Income Security Act of 1974 (ERISA) into law on Labor Day in 1974. The second was by the chairman of the Senate Finance Committee, in the summer of 2005, urging the passage of yet another major revision to ERISA. Although passed by near-unanimous vote of Congress, ERISA is still in need of repair. After more than three decades and dozens of major amendments, it is clear that ERISA has yet to live up to its promise of providing workers with retirement security.

\section{BACKGROUND}

There were numerous proposals to reform pension law in the decade leading up to the enactment of ERISA. A major portion of the impetus was generally attributed to the closing of a plant that manufactured Studebaker automobiles in 1963 , and the termination of a pension plan with 11,000 participants. ${ }^{3}$

\footnotetext{
${ }^{1}$ Official statement of President Gerald R. Ford, issued September 2, 1974, when he signed into law the Employee Retirement Income Security Act of 1974 (ERISA). The entire statement can be found at the Pension Benefit Guaranty Corporation web site, at http://www.pbgc.gov/about/signing.htm.

2 Statement of Sen. Chuck Grassley, Chairman, Finance Committee Consideration, in support of the National Employee Savings and Trust Equity Guarantee Act, in a press release dated July 26, 2005.

${ }^{3}$ Langbein and Wolk, Pension and Employee Benefit Law, Foundation Press, 2000.
} 
The plan involved in the Studebaker plant was a defined benefit pension plan, now sometimes referred to as a "traditional" pension plan, which was to provide for lifetime benefits for retirees. Although employees who had already retired continued to receive their benefits, all the other employees received little or nothing of what they had been promised. ${ }^{4}$

Years of proposals followed the Studebaker plant closing. Finally, on September 2, 1974, President Ford signed Public Law 93-406, the Employee Retirement Income Security Act of 1974 (ERISA). It was based on Congressional findings that "...despite the enormous growth in [employee benefit] plans many employees with long years of employment are losing anticipated retirement benefits owing to the lack of vesting provisions in such plans; that owing to the inadequacy of current minimum standards, the soundness and stability of plans with respect to adequate funds to pay promised benefits may be endangered; that owing to the termination of plans before requisite funds have been accumulated, employees and their beneficiaries have been deprived of anticipated benefits..."

As these Congressional findings indicate, consistently with President Ford's expansive statement and the history leading up to the law's enactment, ERISA was designed primarily to address problems with the defined benefit plan. Defined contribution plans, where participants have individual accounts without any guarantee of a retirement benefit, were low on the horizon. Where they existed at all, they were generally just supplemental to defined benefit plans. In fact, the most popular type of defined contribution plan today, the 401(k) plan, was not even part of ERISA as originally enacted. It was not added to ERISA until four years later.

\section{THE RISE AND FALL OF THE TRADITIONAL PENSION PLAN}

Although covering a wide range of employee benefits, the heart of ERISA was the traditional pension plan. Even the title of the law states that it is mainly concerned with "retirement income," not savings plans or other employee benefits which ERISA does in fact address.

It is sometimes said that the expression "traditional pension plan" means the same thing as "defined benefit plan." As we will see in the next section, the traditional pension plan is only one type of defined benefit plan. It may well have been the only kind that Congress had in mind in 1974 when it enacted ERISA, but today the words "traditional pension plan" need to be used to distinguish this plan from other defined benefit pension plans. The traditional pension plan promised periodic benefits at retirement, usually calculated as some percentage of the participant's income in his or her last years of employment, with factors for length of service and age at retirement.

At its peak in 1985, there were about 112,000 single-employer defined benefit plans insured by the Pension Benefit Guaranty Corporation, the federal agency created by ERISA to guarantee private pension benefits. In 2004, there were only about 26,900 such plans. ${ }^{6}$ Since defined benefit plans that are not traditional pension plans are currently approximately five percent of single-employer defined benefit plans ${ }^{7}$, the actually drop in the number of traditional pension plans is even greater than those numbers would indicate.

Where did all the traditional pension plans go?

They faced many problems over the years, ranging from unrealistic actuarial assumptions used in determining how much should be contributed each year, to poor stock market performance, which exacerbated the problem. In short, traditional pension plans turned out to be more expensive in the long run than employers had counted on. Overly optimistic projections of future earnings, coupled with some actual very good years in the stock market during the $1990^{\prime}$ 's, helped create the illusion that these plans were more affordable than they really were. But that illusion was only temporary. As the true cost of defined benefit plans became clear, many employers started looking for and implementing alternatives such as the 401(k) plan, even though this was never intended to be the primary source of private retirement savings. As workers get older, this trend may be expected to continue.

\footnotetext{
4 Id.

529 U.S.C. $\$ 1001(\mathrm{a})$

${ }^{6}$ Pension Benefit Guaranty Corporation, Pension Insurance Data Book 2004, Spring 2004, page 11.

${ }^{7}$ Id., page 58.
} 


\section{HYBRID PLANS}

A defined contribution plan "...provides for an individual account for each participant and for benefits based solely upon the amount contributed to the participant's account, and any income, expenses, gains and losses, and any forfeitures of accounts of other participants which may be allocated to such participant's account." 8 This account may be a physically separate investment account for the participant, or it may be an account in the sense of a portion of pooled investments. It is sometimes helpful to consider that ERISA also refers to a defined contribution plan as an "individual account plan."

A defined benefit plan is anything other than a defined contribution plan. For years it could be assumed that this referred to a traditional pension plan. But the definition of defined benefit plan is hardly limited to this concept of traditional pension plan, as the only legal requirement seems to be that it not contain individual accounts. In other words, the defining characteristic of a defined benefit plan is that the benefit provided is not based solely on contributions and investment return of a participant's account.

Although this is the definitional distinction between defined contribution and defined benefit plans, there are certain features that tend to be associated with one or the other. For instance, defined benefit plans tend to be backloaded, that is, a disproportionate amount of benefit accruals occur as the participant ages and gets closer to retirement. Defined contribution plans are more likely to pay out their benefits in the form of a lump-sum payment, rather than the traditional annuity payout of a defined benefit plans. Moreover, defined contribution plans tend to include plans that anticipate savings and distributions prior to retirement, while the benefit of defined benefit plans tend to be more for retirement only.

Over time, the concept of a hybrid qualified plan developed. A hybrid would be one of these two major types of plan, which had features resembling the other type of plan.

Two aspects of this warrant clarification. First, the word "hybrid" is misleading, as each plan itself is clearly defined benefit or defined contribution. What is hybrid is the appearance and the function of the plan, not the plan itself. Second, and as a corollary to the first point, there are really two different types of hybrid plan, the defined benefit plan that has some features of the defined contribution plan, and the defined contribution plan that has some features of the defined benefit plan. The temptation to lump these into a single category obscures a great deal of difference between these two types of hybrid plan. For purposes of this article, we will refer to the first as a Defined Benefit Hybrid Plan, and the second as a Defined Contribution Hybrid Plan.

\section{The Defined Benefit Hybrid Plan}

\section{The Cash Balance Plan}

One of the more controversial areas of pension law today involves the "cash balance" plan. The first of these was adopted in 1985, but it was not until the late 1990's that these became popular."

A cash balance plan does not contain the promise of a retirement benefit, the way a traditional plan does. Instead, it creates a hypothetical account for each participant, to which the participant is credited hypothetical contributions plus a hypothetical rate of return. Even after a separation from service the hypothetical return continues to accrue, even though the hypothetical contributions do not. What makes this defined benefit is that the participant is entitled to the amount determined by this formula, regardless of the contributions that are made, and regardless of the actual investment return earned by these contributions.

\footnotetext{
${ }^{8}$ ERISA sec. $3(34)$

${ }^{9}$ Cahill and Soto, "How Do Cash Balance Plans Affect the Pension Landscape?", Center for Retirement Research at Boston College, December 2003, No, 14, page 2.
} 
We call this hybrid because it looks like a defined contribution plan. We can calculate each year's contribution, plus each year's income. Each participant receives an annual statement as though there is an actual account for him or her, even though the account is only hypothetical.

Because this is technically a defined benefit plan, a company which is switching from a traditional pension plan doesn't have to go through the formalities of terminating the traditional pension. It is not subject to taxation on reversion of excess funds, or the cost of funding all the benefits if there is a shortfall. It is precisely because these have been used to cut off future accruals in traditional benefit plans without fully accounting for present accruals, that these plans are so controversial.

If begun from scratch, cash balance plans would not be terribly controversial. The controversy engenders from the transition from traditional defined benefit plans. Older workers ... expected to see their pension benefits rise dramatically as a result of their service just before retirement. Instead, as a result of their companies' adoption of cash balance plans, their pension increases under the old plans ceased... The result is that for many workers, ... their pension benefits stop accruing completely in their final years of service, when their expectation was that during these years, the benefits would build up the most. ${ }^{10}$

At least one case, Cooper et al., vs. The IBM Personal Pension Plan, et al., 274 F. Supp. 2d 1010 (S.D. Ill. 2003) concluded that the cash balance plan was inherently a violation of a special prohibition on age discrimination applicable to defined benefit (but not defined contribution) plans. Most of the cases, however, do not address the issue of whether there is an inherent flaw in these plans, only whether the conversion from traditional pension to cash balance plan was discriminatory.

\section{The Pension Equity Plan}

The Pension Equity Plan is geared toward a participant attaining a retiring benefit equal to a percentage of final earnings. The percentage typically is based on age and years of service. For example, a participant may receive a stated amount of "points" for each year of service, and "points" for attaining a particular age. These points are converted into a percentage, which is applied to the participant's final pay in determining a retirement benefit. In this regard it is similar to the traditional pension plan. However, it has features that resemble the defined contribution plan.

The main defined contribution advantage is for the participant who separates from service in mid-career. Because the traditional defined benefit plan is backloaded, there's typically relatively little benefit for the participant who leaves in mid-career. By contrast, a defined contribution plan participant has an actual account that's been building up year after year, often giving the separated participant a substantial fund to take with him.

The pension equity plan permits the participant to apply his or her percentage to final earnings, even if leaving in mid-career. Although the benefit will certainly be less than it would be by staying until retirement (as the age percentage is lower, the service percentage is lower, and probably the final salary is lower), the participant will still walk away with a substantial, calculable benefit, as opposed to the actuarial calculation of a defined benefit plan that may produce a nominal amount. In short, the pension equity plan has more in the way of protection for participants who leave the employer early than the traditional pension, and has more in the way of protection for participants who join late than the cash balance plan. While these features make is desirable from a participant's point of view, this type of plan is not particularly popular with employers.

10 Campbell v. BankBoston N.A, et al., 327 F.30 1, 17 (1st Cir. 2003) 


\section{The Defined Contribution Hybrid Plan}

\section{The Target Benefit Plan}

The operation of the target benefit plan begins in a way very similar to the traditional pension plan. Each employee's earnings are evaluated and projected into the future, and there is a calculation made as to how much needs to be contributed in order to fund a targeted retirement benefit.

Unlike a traditional pension, however, this amount isn't guaranteed. Instead, the calculated amount is set aside each year, and invested. What the participant is entitled to is the invested amount in the account, plus actual investment return, which may ultimately be greater than or less than the projected benefit. Because this is the sole basis of determining the participant's benefit, it is a defined contribution plan, even though it resembles defined benefit.

\section{Age-Weighted And New Comparability Plans}

Originally the profit sharing plan was one of the simplest of the qualified plans. Each year, the employer would determine the amount of profits available for contribution to the plan, and the contribution would be allocated among participants in proportion to their compensation. Just about the only wrinkle was the profit sharing plan, like any qualified plan, could be integrated with Social Security. In the case of a profit sharing plan integration meant that there could be disproportionately smaller contributions for the portion of a worker's income that was eligible for Social Security retirement benefits, to reflect the fact that the employer was already subsidizing those benefits. Otherwise, the profit sharing plan started out as a very simple arrangement. In 1978, the simplicity of the profit sharing plan was changed with the introduction of the $401(\mathrm{k})$ plan, a type of profit sharing plan where participants had the option of taking cash or having a contribution made to the plan.

More recent years have brought more variations on the profit sharing theme. The "age-weighted" profit sharing plan is a profit sharing plan where compensation isn't the only factor taken into account when allocating the annual contribution. Age can be used as a factor, and length of service can also be taken into account. Thus, if there are two employees with equal compensation, the one who is older and/or has more years of service, will have a greater share of the annual contribution allocated to his or her account. This favoring of older employees makes it resemble the defined benefit plan. However, since it is still a defined contribution plan, the employer adopting this is spared the actuarial costs and other special burdens usually attendant to defined benefit plans.

A plan that qualifies under "new comparability" rules isn' $\_$necessarily a hybrid plan, but it can be used as such. New comparability simply means that when determining whether a plan violates the prohibition against discriminating in favor of higher-paid employees, the employer isn't limited to a strict comparison of what percentage of compensation is contribution. For instance, a plan may use "cross testing" to determine whether it is discriminatory. This means "contributions are converted, using actuarial assumptions, to equivalent benefits payable at normal retirement age, and these equivalent benefits are tested in a manner similar to the testing of employerprovided benefits under a defined benefit plan." 11 Although new comparability may be applied to any defined contribution plan, it is generally used with profit sharing plans.

In our attempt to look at the future of qualified plans, it is important to have an understanding of these hybrid plans. There would be no hybrid plans if not for perceived shortcomings in both defined contribution and defined benefit plans. Hybrid plans are an attempt to remedy such shortcomings. However, when looking at retirement savings policy going forward, it is important to distinguish between the two major categories of hybrid plans. The defined benefit plan that has features of a defined contribution plan is rarely adopted, except as less-costly alternative to terminating a traditional pension plan. The defined contribution plan that has features of a defined benefit plan has merits that would justify its adoption regardless of what kind of plan, if any, came before. In short, the defined benefit

\footnotetext{
11 "Non-Discrimination Requirements for Certain Defined Contribution Retirement Plans," "Background" section for promulgation of Treas. Regs. Sec. 1.401(a)(4)-8, June 19, 2001.
} 
plan that has features of the defined contribution plan, such as the cash balance plan, is really vestigial of a traditional pension era. As traditional pension plans recede into history for most companies, there will eventually be little need for termination substitutes like the cash balance plan.

\section{RECENT DEVELOPMENTS}

In 2004, Congress enacted the Pension Funding and Equity Act. ${ }^{12}$ PFEA provided temporary partial relief from pension obligations, in order to stave off plan terminations. Under the Act, the interest rate used for plan years beginning in 2004 and 2005 would be based on the rate of return available with long-term investment-grade corporate bonds rather than 30-year Treasury bonds. This rate would be used for determining current liability for funding and deduction purposes and in determining PBGC variable rate premiums. Since corporate bonds have a higher rate of return than Treasury bonds, this change gave employers a smaller present value for their future pension obligations. Additional relief was available for certain airline and steel industry plans.

While intending some relief from pension obligations, this law did not stem the building sense of impending crisis in the private pension system. The crisis was highlighted by a PBGC deficit of $\$ 23.5$ billion for the year $2004 .^{13}$

On January 10,2005 , the Bush administration released its plan for dealing with the pension crisis. At the heart of the plan were rules related to increased funding requirements, changes in the actuarial assumptions that could be used, and increases in the premiums that companies would have to pay for PBGC coverage. Then, on June 9, 2005, the Pension Protection Act of 2005 ("PPA") was introduced into Congress, which contained a modified form of the Bush plan.

In order to understand the nature of the problem, it is important to remember that even the $\$ 23.5$ billion PBGC deficit reflects only plans with actual payments assumed by PBGC, and does not include plans with prospective defaults. To get some idea of the potential magnitude of the problem, PBGC calculates that total current pension underfunding comes to $\$ 353.73$ billion. ${ }^{14}$ And this is underfunding based on current actuarial assumptions used by corporations, as more stringent assumptions would produce a larger underfunding figure.

The defined benefit pension system is beset with structural flaws that undermine benefit security for workers and retirees and leave premium payers and taxpayers at risk of inheriting the unfunded pension promises of failed companies. ${ }^{15}$

As of this writing, PPA is the most current form of the pension reform proposals enacted by either house of Congress. More recently, on June 9, 2005, the Senate Finance Committee unanimously approved S.219, the "National Employee Savings and Trust Equity Guaranty Act of 2005," which was its own approach to addressing the pension problem. It cannot be said with certainty at this time which provisions, if any, of either of these will ultimately be enacted. However, PPA provides an outline of the options available to Congress for addressing the pension problem.

The principal focus of PPA is a carrot-and-stick approach to making sure that pension plans are adequately funded. Towards this end, the bill would establish standards for actuarial assumptions so that these assumptions could not arbitrarily be used to understate liability, prohibit increases of benefits or lump sum distributions for union plans that are less than 80 percent funded, and require accelerated contributions for plans that are less than 60 percent funded.

The annual PBGC premium would be increased from its current $\$ 19$ per participant to $\$ 30$ per participant. In a sense this isn't an increase, just an inflation adjustment since the last increase 14 years ago, but it would still help the solvency of PBGC. The earlier Bush proposal included the concept of rating companies, that is, charging more for

\footnotetext{
${ }^{12}$ Pub. Law 108-218

13 PBGC Pension Insurance Data Book 2004.

14 PBGC press release June 7, 2005.

15 Testimony of Bradley D. Belt, Executive Director, Pension Benefit Guaranty Corporation, before the Senate Committee on Budget, June 15, 2005.
} 
companies that present a greater risk, but this did not make it into this legislation. However, there is a small nod in this direction, in that this increase will be phased in over three years for plans with less than 80 percent funding, and over five years for plans that are at least 80 percent funded.

PPA also introduces a new concept, encouraging overfunding in good years. Instead of limiting deductibility by the amount of the current liability, PPA permits deductions of up to 150 percent of the current liability. This way companies can load the pension plan during good years, as a buffer to protect them against bad years.

The lead sponsor of PPA is John A. Boehner (R-OH), Chairman of the House Education \& the Workforce Committee. In a statement accompanying the bill, Rep. Boehner had also indicated strong support for legitimatizing cash balance plans, that is, legislatively overruling some of the objections that court cases have had to the conversion of traditional pension plans to cash balance plans.

While PPA addresses a wide range of funding issues, there are some matters that are not addressed by it, or are only partially addressed:

\section{Risk-Based PBCG Premiums}

The administration proposal included plans to charge a higher PBGC premium for companies with credit ratings below investment grade. This does not appear in PPA, and might safely be considered abandoned for now. Aithough this was probably removed because of its political unpalatability, such a sliding scale for premiums would have a distinct advantage, which would be to deter companies that are not solvent enough to keep defined benefit promises from making those promises to begin with.

\section{Disparity Between Pension Accounting And Financial Statement Accounting}

PPA does not adequately address the disparity between pension accounting and financial statement accounting. In a sense, this is more of a securities law issue than a pension law issue, as corporations are able to use pension plans to inflate their net worth. It may be that ERISA started out to protect workers, and is now evolving to protect taxpayers (i.e., to avoid a PBGC bailout). However, ERISA needs to continue to evolve, to protect investors, that is, so that pension assumptions are not used to mislead investors. "Because companies assume their investments will do well over time, they can generally use the anticipated success of their pension funds to reduce a given year's labor costs, bolstering the corporate bottom line."16

The Sarbanes-Oxley Act of $2002^{17}$ did not address directly the problem of manipulation of corporate net worth through pension accounting conventions. However, Sarbanes-Oxley did direct the Securities and Exchange Commission to report on "off balance sheet" arrangements, which the SEC interpreted liberally to include pension plans. On June 15, 2005, the SEC staff issued its report to the President and the Congress, based on a sample of 100 of the largest U.S. companies, and an additional 100 companies selected at random (the "SEC Report"). The report found $\$ 86$ billion in pension underfunding for the companies in the sample. However, on their balance sheets, these same companies showed these plans as having a positive net asset value (assets in excess of liabilities) of approximately $\$ 91$ billion. ${ }^{18}$

PPA partially addresses the accounting issue by modifying an accounting practice called "smoothing." Essentially, smoothing means that if there is a bad investment year, the losses can be allocated over several years, creating the illusion of more assets in a plan at any given time than there really are.

\footnotetext{
16 Walsh, Mary Williams, Overhaul Plan For Pensions Is Outlined, The New York Times, January 11, 2005.

17 Pub. Law 107-204.

18 United States Securities and Exchange Commission, Report and Recommendations Pursuant to Section 401(c) of the SarbanesOxley Act of 2002 on Arrangements with Off-Balance Sheet Implications, Special Purpose Entities, and Transparency of Filings by Issuers, June 15, 2005, pp. 54-56
} 
Smoothing comes from Financial Accounting Standards Board (FASB) Statement 87, "Employers' Accounting for Pensions," issued in 1985. The application of FASB Statement 87 results in the smoothing effect on earnings from year to year and the possible nonrecognition of significant pension liabilities (that is, moving such liabilities off balance sheet).

FASB Statement 87 states that annual pension expense for defined benefit plans consists of the following components:

1) Service cost

2) Interest cost on the projected benefit obligation

3) Actual return on plan assets

4) Amortization of unrecognized prior service cost

5) Amortization of unrecognized gains and losses

6) Amortization of the unrecognized net asset or obligation for the plan at the time FASB Statement 87 was first adopted.

Smoothing occurs from items 4 through 6 . Companies amortize these items over the average remaining service lives of the employee group(s) affected. The liabilities for unamortized prior service cost and unamortized unrecognized gains and losses are required to be disclosed in a pension footnote to the financial statements. However, they do not make it to the balance sheet unless the minimum liability provisions of Statement 87 apply. The minimum liability provision requires recognition of an additional liability if two conditions are met at the balance sheet date:

1) the fair value of plan assets is less than the accumulated benefit obligation, and

2) any liability already recognized is less than the unfunded accumulated benefit obligation.

The liability that gets recorded under these circumstances is not usually close to the actual unfunded plan liability that may exist since it is based on the accumulated benefit obligation rather than the projected benefit obligation. The accumulated benefit obligation is the expected amount that will be payable to the current employee group at current salary levels. The projected benefit obligation is the expected amount that will be payable at future anticipated salary levels. So the accumulated benefit obligation is always less than the projected benefit obligation.

Further, if a minimum liability is recorded, Statement 87 requires that it be charged to an intangible asset account and credited to other comprehensive income. This keeps the adjustment off of the current period's income statement and adds to the smoothing effect on earnings.

How does PPA address the smoothing issue? It shortens the numbers of years over which the smoothing can occur. This reduces the smoothing problem, but it does not eliminate it. More importantly, smoothing is only one of many issues, as there are numerous conventions and assumptions used in valuing defined benefit plans that produce a great deal of variation. The SEC Report notes that "...estimation of retirement plan liabilities depends on multiple actuarial and other estimates and assumptions. Because of the size of retirement obligations and their sensitivity to certain assumptions, even relatively small changes in those assumptions or estimates can significantly change the estimated obligation or pension expense."19

\section{Participant Losses On Traditional Pension Conversions}

A core issue when looking at conversions of traditional pension plans to cash balance plans is the question of how much credit is given to the participant at the time of the conversion. In this regard, the House Education \& the Workforce Committee sponsors are particularly glib. A Committee bill summary states that "... under the Employee Retirement Income Security Act (ERISA) benefits earned under a traditional plan cannot be reduced when they are converted to a cash balance plan. Despite assertions to the contrary, vested benefits earned by workers are never reduced in a cash balance conversion." 20 The flaw in this statement is that, while "vested benefits" may not be

19 Id., page 53

${ }^{20}$ House Education \& the Workforce Committee, Bill Summary, June 9, 2005. 
reduced, the way these "vested benefits" are calculated is backloaded, so that the amount the participant is entitled to is far less than what he or she would be entitled to under a method that credited him or her with a benefit based on what he or she has earned so far.

As one expert has noted, "The [Internal Revenue] Code and ERISA preclude certain types of back-loading by proscribing plan formulas that delay pension accruals until the end of the employee's work life. However, even with these statutory safeguards, as a matter of economics the most valuable pension accruals under traditional defined benefit plan formulas occur late in the employee's career when her salary is higher and she is closer to retirement.",2!

Viewed another way, defined contribution plans and cash balance plans favor the young, while traditional pension plans favor the old. For a participant to put in 20 years of work under a traditional pension plan and then be forced to switch to a cash balance pian means that the participant is deprived of the central advantage of either one. It is interesting to note that the pension equity type of defined benefit hybrid plan would protect the participant in a midcareer plan switch, and, perhaps for this reason, these plans are not anywhere as near as popular with employers as the cash balance plan.

Some of these omissions of PPA have been addressed by S.219, the National Employee Savings and Trust Equity Guaranty Act of 2005. However, perhaps the greatest omission of all in PPA is not meaningfully addressed in S.219. That omission is the failure to recognize the fact that if defined benefit plans contain more worker protections, then they will become more expensive. If they become more expensive, then more employers will switch to defined contribution plans (if indeed they have any qualified plans at all). None of the current proposals satisfactorily address the changes in the law that need to be made to protect participants in defined contribution plans.

\section{Marginalizing Defined Contribution Plans}

PPA does little to shore up defined contribution plans. Historically we have seen the move from the traditional pension plan to defined contribution plans, particularly the 401(k) plan. Any new legislation to increase accountability of pension plans will necessarily increase cost, and this will hasten the exodus of many of the borderline plans.

PPA attempts to preserve accountability of defined benefit plans. Paradoxically, it also appears intended to stem the loss of defined benefit plans. As the Committee bill summary states, "Without comprehensive reform...more companies will stop providing defined benefit pension plans..."22 The implication is that it is a bad thing for companies to stop providing defined benefit plans. The reality is that if a company cannot afford the expensive, longterm commitment that a defined benefit plan entails, then it will only do long-term harm by making a promise it cannot keep. By making sure that companies will not offer defined benefit plans unless they truly can afford them, in fact there will be more companies that stop providing these plans. Although there are exceptions to the general economic principle that increases in cost will reduce the demand, there is no exception that the sponsors of PPA have identified that would be applicable here. PPA seems to assume that there is a standard benefit package that includes a defined benefit plan and a $401(\mathrm{k})$ plan, where the reality may be the complete absence of the defined benefit plan.

It is instructive to see what the SEC Report required by Sarbanes-Oxley has to say about defined contribution plans. While devoting more than 10 pages to defined benefit plans, the report only acknowledges defined contribution plans in passing: "The future risks and rewards of these plans rest with employees, not employers. Thus, the accounting for defined contribution plans is quite straightforward and does not raise significant off-balance sheet questions; as such, the accounting for these plans is not addressed in this Report, ${ }^{, 23}$ In short, investors, lenders, and underwriters know exactly what to expect when dealing with a company's defined contribution plan, while a defined benefit plan's impact on a company's net worth is founded on multiple conjectures. It may be time to acknowledge

21 Zelinsky, Edward A., The Defined Contribution Paradigm, Yale Law Journal, December 2004 (114 Yale L.J. 451).

${ }^{22}$ House Education \& the Workforce Committee, Bill Summary, June 9, 2005.

${ }^{23}$ United States Securities and Exchange Commission, "Report and Recommendations Pursuant to Section 401(c) of the SarbanesOxley Act of 2002 on Arrangements with Off-Balance Sheet Implications, Special Purpose Entities, and Transparency of Filings by Issuers," June 15, 2005, p. 49. 
that it is not the typical company that can afford a defined benefit plan, and further that there is no universai advantage of a defined benefit plan over a defined contribution plan.

It may also be that the expectations of workers have changed, and that baby boomers are in a transitional period between the generation that thought of traditional pensions as the norm, and the generation that thinks of defined contribution/individual account plans as the norm. "Americans today primarily conceive of and implement retirement savings in the form of individual accounts. ${ }^{24}$

Accordingly, with the further demise of the defined benefit plan, the question is this: how can defined contribution plans fill in the gap left by defined benefit plans? The Enron debacie confirmed what we knew all along, that the $401(\mathrm{k})$ plan is not a substitute for a traditional pension plan. What, then, is?

\section{ANALYSIS}

As we have seen, the primary focus of ERISA was on traditional pension plans. In 1974, defined contribution plans were ancillary, supplemental plans. This resulted in two problems we face today: First, little attention was paid in ERISA as to the special kind of protection need by participants in defined contributions plans, as distinguished from protection needed by participants in defined benefit plans. Second, there is a patchwork of different laws related to retirement savings accounts, ERISA plans and otherwise, without a consistent set of unifying principals.

Under current law there are large inconsistencies among the different types of retirement savings plans that are based on individual accounts. There are qualified defined contribution plans (such as $401(\mathrm{k})$ plans), there are 403(b) plans for employees of certain tax-exempt organizations, and there is the IRA. Each of these has similar but different rules, in particular with regard to the amount that can be contributed. Thus, for instance, in the year 2005, the maximum deductible contribution to the most generous defined contribution plan is $\$ 42,000$, but the maximum is $\$ 14,000$ for $401(\mathrm{k})$ and $403(\mathrm{~b})$ plans (plus $\$ 4,000$ catch-up contributions permitted for individuals age 50 and over) and $\$ 3,000$ for IRAs (plus $\$ 500$ catch-up contributions for individuals age 50 and over).

The trend towards $401(\mathrm{k})$ plans is really two concurrent trends. One is the trend away from defined benefit plans towards defined contribution plans. The other is the trend away from plans that reiy on employer contributions towards plans that rely on employee contributions. As more and more retirement savings are funded by the individual rather than the employer, it makes less and less sense that the amount a person can contribute each year is limited by a choice of plan made by the employer. Thus, a single retirement plan restructure, which would permit a unified maximum amount to be contributed by each individual, would permit each person to implement his or her own retirement savings program regardless of what his or her employer is doing.

It is incongruous today that there is rarely any expectation of lifelong employment with one company, and yet the laws related to retirement planning are heavily reliant on long-term employer beneficence. That was a questionable premise even in 1974, and it makes less sense today. While it may continue to make sense to give employers incentives to contribute to an employee's account, it may be time to give the employee free rein to make up the difference if the employer's contribution is less than the maximum.

Current law includes tax incentives, so that if a company wants to provide a retirement benefit to key employees there must be a minimum amount of coverage provided to the rank-and-file employees. These rules can be retained in a modified form. That is, any key employee will be denied a deduction for a contribution to a defined contribution plan or an IRA, unless there's a minimum amount given to the rank-and-file. This rule can be retained without perpetuating separate legal structures and limits for retirement savings plans serving the same function.

One of the interesting aspects of the various savings programs is the concept of "catch-up contributions" that we see in $401(\mathrm{k})$ plans, $403(\mathrm{~b})$ plans, and IRAs. It is a concept of fairly recent origin, but it is one that warrants closer

\footnotetext{
${ }^{24}$ Zelinsky, Edward A., The Defined Contribution Paradigm, Yale Law Journal, December 2004 (114 Yale L.J. 451).
} 
examination. After all, catch-up contributions make all of these savings plans hybrid, in the sense that they are individual account plans with a little piece of defined benefit in them, that is, the ability to make larger contributions for older individuals. It may be possible to expand these plans, to bridge the gap between them and the other defined contribution hybrid plans - the target benefit plan, and the age-weighted and new comparability profit sharing plans.

By way of example, suppose there were an IRA that permitted $\$ 20,000$ annual contributions until age 40; $\$ 30,000$ annual contributions for anyone in his or her 40 's; $\$ 40,000$ annual contributions for anyone in his or her 50 's; and $\$ 50,000$ annual contributions for anyone in his or her 60 's. The employer would be free to contribute to these IRA's, and it could deduct the contributions to higher-paid employee IRAs if those contributions were made pursuant to a non-discriminatory plan. Any shortfall in the contribution to the IRA of a rank-and-file employee could then be made by the employee. Such a program would resemble the defined contribution plans that have defined benefit features, but it would be immune to many of the problems that have faced defined contribution plans as well as defined benefit plans. Given Americans' low savings rate, there's no danger of a precipitous drop in tax revenue from so generous a plan, but individuals who wish to save responsibly for retirement would have the opportunity to do so, independently of the whims of their employers. And the employer that did choose to contribute such a plan would have a financial statement unblemished by a liability fixed with seeming certainty at an amount that is inescapably arbitrary.

\section{CONCLUSION}

In the more than 30 years since the passage of ERISA, both the law and its uses have undergone numerous changes. The traditional pension plan, which lay at the heart of ERISA, has been supplanted, often by a cash balance plan or a $401(\mathrm{k})$ plan. It may be that neither of these satisfactorily address long-term pension issues, and that Congressional efforts to protect defined benefit plans are misplaced. It may be that the best approach lies beyond defined benefit plans completely, using defined contribution plans that permit greater contributions for older individuals. These would provide the greatest advantage of defined benefit plans, without their numerous shortcomings. 
NOTES 